\title{
Biochemical Estimation of Healthy and Infected Graminicolous Seeds
}

\author{
A. R. Gulhane, Shilpa V. Khambalkar* and G. K. Giri \\ Sorghum Research Unit, Dr. PDKV, Akola, Maharashtra, India \\ *Corresponding author
}

\section{A B S T R A C T}

\begin{tabular}{|l|}
\hline Key words \\
Graminicolous \\
Seeds, Biochemical \\
\hline Article Info \\
\hline $\begin{array}{l}\text { Accepted: } \\
\text { 28 March } 2018 \\
\text { Available Online: } \\
\text { 10 July } 2018\end{array}$ \\
\hline \hline
\end{tabular}

Keywords

Graminicolous Seeds, Biochemical

\section{Introduction}

Gramineae is an important family which consist of all cereals i.e. rice, wheat, sorghum, pearl millet and grasses. These are used as a staple food all among the world, which rice is the first then wheat, maize, barley and sorghum. Rice is the most perfect staple food crop of the world, rice straw is used as fooder, manure, roofing material and straw board, rice husk is used in processing of bricks. In rice Curvularia lunata, C. geniculata were predominant fungi responsible for kernel discoloration and $B$. oryzae a second important pathogen in Vidarbha. Twenty seven fungal species associated with rice seed sample among them most prominent fungi was Bipolaris oryzae (82.08\%). The leaf blight/ brown spot caused by Bipolaris oryzae and
Curvularia lunata were recorded in rice crop (Bharti and Raut, 2009; Archana and Prakash, 2013; Nyval et al., 1995; Safari and Kavini, 2008; Kamaludcen et al., 2013). The incidence of Bipolaris sorokiniana was found highest in wheat grain. The leaf blight and seedling blight disease caused by $B$. sorokiniana was reported in leaf of wheat crop. The incidence of leaf blight caused by Drechslera spp. was also reported in corn crop (Malekar et al., 2010; Malekar Main, 2002; Azad et al., 2009). The few fungi infect sorghum spikelete tissues during early stages of grain development and seed borne these are Viz., Curvularia lunata, Drechslera tetramera, Bipolaris sorghicola, Drechslera longirostreta, Fusarium moniliforme, Alternaria alternata, Aspergillus niger (Islam et al., 2009; Panchal and Dhale, 2011). The 
fungi Curvularia lunata, C. pallescens, Drechslera specifera and D. halodes reduced the crude fat between 3.83 and 8.95 per cent, sugar content between 26.14 and 31.37 per cent and ash content 6.35 and 10.40 per cent in sorghum seed. Reduction of sugar in the seed might be due to utilization of sugar by seed borne fungi (Ingal, 1976; Jamaluddin et al., 1977; Neucere and Sumrell, 1980; Subramanian et al., 1980; Subramanian et al., 1983). Seed borne infection of Drechslera oryzae decreases starch and sugar content of rice grains between 25 to 85 and 71 to 89 per cent (Jha, 1983). The present investigation was to measure the total phenol, phenolic and total sugar contain the infected and healthy seed of sorghum, wheat, paddy and pearl millet.

\section{Materials and Methods}

\section{Preparation of alcoholic extract}

The prepared seed powder of infected and healthy seed was weighed ( 1 to $5 \mathrm{~g}$ ) and then boiled with three volumes of $(\mathrm{u} / \mathrm{v})$ distilled ethanol on a boiling water bath, for one hour. A prolonged reflux was used to prevent loss of ethanol during the boiling. The slurry, thus obtained was strained through the four layers of muslin cloth. The strained materiel was centrifuged at $8000 \mathrm{rpm}$ for $20 \mathrm{~min}$ at room temperature and the supernatant was stored at $-12^{\circ} \mathrm{C}$ for further use of estimation of total phenols, phenolic acid and total sugar.

\section{Estimation of phenols}

\section{Chemicals required}

Folin ciocalteau

$\mathrm{NaOH}$

\section{Procedure}

Extracted tissues were analyzed for total phenol by using Spectrophotometer. Method suggested by Farkas and Kiraly (1962) was employed to determine total phenol in each extracted sample.

Folin ciocalteau was diluted by equal amount of distilled water. In a $25 \mathrm{ml}$ tube, one $\mathrm{ml}$ extract was taken and in it one ml diluted Folin ciocalteau reagent and two ml 20\% $\mathrm{NaOH}$ were added and shaken thoroughly. This solution was heated in hot water bath for one minute, which turned blue after heating. The tube was then cooled under tap water and diluted with $25 \mathrm{ml}$ distilled water. The blank solution without extract was prepared in the same way. This blank solution was taken in a tube and its absorbance was adjusted to zero at $650 \mathrm{~nm}$ with Spectrophotometer. The prepared solution with extract was kept in the tube by one washing and absorbance was compared with standard curve and the values were worked out.

\section{Standard curve for total phenols}

The stock solution was prepared by dissolving $100 \mathrm{mg}$ D- catechol in $10 \mathrm{ml}$ distilled water. This stock solution was used for preparing seven dilution of different concentration as given below.

From each dilution one ml solution was taken in test tube of $25 \mathrm{ml}$ capacity separately and in it one $\mathrm{ml}$ Folin ciocalteau reagent (previously diluted) and two $\mathrm{ml} 20 \% \mathrm{NaOH}$ were added after shaking. The tube were heated in hot water bath for one minute. The solution which turns blue was allowed to cool down and diluted with $25 \mathrm{ml}$ distilled water. A blank without stock solution was prepared in similar way for setting zero of Spectrophotometer. Reading of absorbance at $650 \mathrm{~nm}$ with each concentration was recorded. The standard curve was plotted with concentration of Dcatechol (pg) on $\mathrm{x}$ axis against reading of Spectrophotometer on $\mathrm{y}$ axis value from the unknown dilution were worked out by comparing with these curves. 
Estimation of phenolic acid (Folin ciocalteau method)

\section{Chemicals required}

Alcohol

Folin ciocalteau

Tannic acid

Phenolic acid

Methanol

\section{Procedure}

In the test tube of $25 \mathrm{ml}$ capacity one $\mathrm{ml}$ alcohol extract was taken with the help of pipette and one $\mathrm{ml}$ of Folin ciocalteau reagent was added in it with $2 \mathrm{ml} 1 \mathrm{~N} \mathrm{NaOH}$ solution.

This solution was incubated for $15 \mathrm{~min}$ in a hot water bath at $60^{\circ} \mathrm{C}$ and then allowed to cool. The volume was made upto $50 \mathrm{ml}$ with distilled water and filtered. To adjust the zero of Spectrophotometer at $560 \mathrm{~nm}$, the blank without extract was prepared by using same procedure. The prepared solution was taken in the Spectrophotometer tube and absorbance was then compared with standard curve prepared from tannic acid and value of phenolic acid were worked out. On the basis of standard curve the phenolic acid were estimated in samples (Bray and Thorpe, 1944).

\section{Standard curve for phenolic acid}

The standard solution of tannic acid was prepared by dissolving one mg tannic acid in one $\mathrm{ml}$ water. The dilution of different concentration were prepared as $0.1,0.2,0.3$, 0.4 and $0.5 \mathrm{ml}$ and made up one $\mathrm{ml}$ with methanol. From each dilution one ml solution was taken in $25 \mathrm{ml}$ capacity tube with pipette and added $2 \mathrm{ml} 20 \% \mathrm{Na}_{2} \mathrm{Co}_{3}$ solution. The solution was incubated for $15 \mathrm{~min}$ in hot water bath at $60^{\circ} \mathrm{C}$ and allowed to cool and volume was made upto $50 \mathrm{ml}$. A blank without stock solution was prepared in the same way and was used to adjust the zero at $560 \mathrm{~nm}$. Each dilution with Tannic acid was taken for absorbance and, the values were recorded. Standard curve was plotted with known of tannic acid on $\mathrm{x}$ axis against Spectrophoto meter reading on y axis by comparing the reading of alcohol extracts on y axis.

\section{Determination of sugar from seed sample}

\section{Chemicals required}

\author{
Alcohol \\ Lead acetate \\ Potassium oxalate \\ $0.5 \mathrm{~N} \mathrm{HCl}$ \\ $\mathrm{NaOH}$ \\ Acetic acid \\ Copper sulphate \\ Unhydrous sodium carbonate \\ Rochelse salt \\ Potassium iodide \\ Unhydrous sodium sulphate \\ Pyrex test tube \\ Sulphuric acid \\ Starch indicator
}

\section{Procedure}

Two gm of sample was taken for extraction (dried at $60^{\circ} \mathrm{C}$ and grind to fine powder).

Extraction was done in different grades of alcohol starting from $80 \%, 60 \%, 40 \%$ and finally in water.

The first extraction (80 \% alcohol) was complete by boiling in water bath using a reflux condenser for half an hour and the extraction was continued for $24 \mathrm{~h}$. The supernatant was filtered into a flask through Whatman's filter paper (No 42). The residue left was further extracted with other grades of alcohol and water in similar manner. At the end of every $24 \mathrm{~h}$. the supernatant was filtered and added to original extract collected. 
The total volume was make up to $250 \mathrm{ml}$ with distilled water.

$25 \mathrm{ml}$ aliquot from this was used for clarification and estimation of sugar.

$25 \mathrm{ml}$ aliquot was taken in a beaker and all the alcohol was evaporated.

To the residue left, $10 \mathrm{ml}$ of distilled water was added and colloidal substances were precipitated by adding one $\mathrm{ml}$ of basic lead acetate and removed by filtering through Whatman's filter paper (No. 42).

The excess of lead acetate in filtrate was precipitated as lead oxalate by adding two $\mathrm{ml}$ of saturated potassium oxalate and filtered.

Filtrate was made up to $50 \mathrm{ml}$ in volumetric flask with distilled water and $25 \mathrm{ml}$ was used for hydrolysis of non reducing sugars.

To $25 \mathrm{ml}$ clarified solution taken in $100 \mathrm{ml}$ volumetric flask was added $12.5 \mathrm{ml}$ of $0.5 \mathrm{~N}$. $\mathrm{HCl}$ and placed over a water bath for half an hour for inversion of non-reducing sugars into reducing sugars.

The flasks were cooled, a drop of methyl red was added and contents were added neutralize $0.5 \mathrm{~N}$ sodium hydroxide.

This solution was made acidic by adding a drop of acetic acid and total volume made to $100 \mathrm{ml}$ mark with distilled water.

Five $\mathrm{ml}$ of the aliquot was taken from the original solution and reducing sugars were estimated as per the method described by Somogyi, 1952.

The reagent for analysis for sugar consisted 8 gm Copper sulphate and $30 \mathrm{gm}$ anhydrous sodium carbonate +30 gm Rochelse salt +8 gm Potassium iodide $+180 \mathrm{~g}$ anhydrous sodium sulphate $+40 \mathrm{ml}$ sodium hydroxide and $10 \mathrm{ml}$ potassium iodide per liter.

Five $\mathrm{ml}$ of sugar reagent and $5 \mathrm{ml}$ of clarified solution were mixed in Pyrex test tube $(25 \mathrm{x}$ $200 \mathrm{~mm}$ ) covered with stopper and heated by immersing in vigorously boiling water bath for 15 minutes.

The tube were removed, cooled and one $\mathrm{ml}$ of $2.5 \%$ Potassium iodide was added by side of the test tube without agitation.

Three ml of Sulphuric acid ( $2 \mathrm{~N}$ ) was added to the tube with vigorous shaking and the excess of iodine liberated was filtered against 0.005 $\mathrm{N}$ Sodium thiosulphate run through micro burette until the solution turned pale yellow.

Two drop of starch indicator were added and titrated till solution become colourless.

Pair of flask containing $5 \mathrm{ml}$ of reagent + sugar solution of known concentration were run with each batch and titration was continued as used.

The estimation of total sugar was done with hydrolyzed solution as usual manner.

The amount of non-reducing sugar was obtained from difference between total sugars.

And the reducing sugar and multiply by the factor 0.95 (Nelson, 1944), (Shields and Burnett, 1960).

\section{Results and Discussion}

The biochemical properties viz. total sugars, phenolic acid and total phenol were studied from mouldy/discolored seed samples of sorghum, wheat, paddy and pearl millet.

Collected from various places of Vidarbha region. 


\section{Standard curve for total phenols}

\begin{tabular}{|c|}
\hline Stock solution \\
\hline $0.25 \mathrm{ml}$ \\
\hline $0.50 \mathrm{ml}$ \\
\hline $0.75 \mathrm{ml}$ \\
\hline $1.00 \mathrm{ml}$ \\
\hline $1.25 \mathrm{ml}$ \\
\hline $0.50 \mathrm{ml}$ \\
\hline $1.75 \mathrm{ml}$ \\
\hline
\end{tabular}

\begin{tabular}{|c|c|}
\hline Distilled water & Concentration \\
\hline $99.75 \mathrm{ml}$ & $25 \mu \mathrm{g}$ \\
\hline $99.50 \mathrm{ml}$ & $50 \mu \mathrm{g}$ \\
\hline $99.25 \mathrm{ml}$ & $75 \mu \mathrm{g}$ \\
\hline $99.00 \mathrm{ml}$ & $100 \mu \mathrm{g}$ \\
\hline $98.75 \mathrm{ml}$ & $125 \mu \mathrm{g}$ \\
\hline $98.50 \mathrm{ml}$ & $150 \mu \mathrm{g}$ \\
\hline $98.25 \mathrm{ml}$ & $175 \mu \mathrm{g}$ \\
\hline
\end{tabular}

Table.1 Influences of total sugar, phenolic acid and total phenol $(\mu \mathrm{g} / \mathrm{g})$ contains in healthy and diseased seeds of Sorghum, Wheat, Paddy and Pearl millet

\begin{tabular}{|c|c|c|c|c|c|c|}
\hline \multirow[t]{2}{*}{ Seed } & \multicolumn{3}{|c|}{ Healthy seed $(\mu \mathrm{g} / \mathrm{g})$} & \multicolumn{3}{|c|}{ Diseased seed $(\mu \mathrm{g} / \mathrm{g})$} \\
\hline & $\begin{array}{l}\text { Total } \\
\text { sugar }\end{array}$ & $\begin{array}{c}\text { Phenolic } \\
\text { acid }\end{array}$ & $\begin{array}{c}\text { Total } \\
\text { phenol }\end{array}$ & $\begin{array}{l}\text { Total } \\
\text { sugar }\end{array}$ & $\begin{array}{c}\text { Phenolic } \\
\text { acid }\end{array}$ & $\begin{array}{c}\text { Total } \\
\text { phenol }\end{array}$ \\
\hline Sorghum & 357.14 & 5.08 & 3.99 & 17.80 & 4.42 & 3.46 \\
\hline Wheat & 247.05 & 3.62 & 4.05 & 16.52 & 3.02 & 2.02 \\
\hline paddy & 388.60 & 3.92 & 2.96 & 12.80 & 2.65 & 1.71 \\
\hline Pearl millet & 340.2 & 6.92 & 3.11 & 14.05 & 4.79 & 3.03 \\
\hline
\end{tabular}

\section{Total sugars}

The data presented in Table 22 revealed that, maximum total sugar contains were recorded in healthy seed of sorghum, wheat, paddy and pearl millet which was in the range of 247.05 $\mu \mathrm{g} / \mathrm{g}$ to $388.60 \mu \mathrm{g} / \mathrm{g}$ of seed, whereas, in diseased seed total sugars recorded in between $12.80 \mu \mathrm{g} / \mathrm{g}$ to $17.80 \mu \mathrm{g} / \mathrm{g}$ of seed. Among different seeds the maximum total sugars recorded in paddy $388.60 \mu \mathrm{g} / \mathrm{g}$ and minimum in wheat $247.05 \mu \mathrm{g} / \mathrm{g}$. Diseased seeds of sorghum exhibited the maximum total sugar $17.80 \mu \mathrm{g} / \mathrm{g}$ and minimum were recorded in paddy $12.80 \mu \mathrm{g} / \mathrm{g}$ of seed. The reduction of sugar in seed might be due to the utilization of carbohydrates mostly the starch in the form of sugar by the seed borne fungi. (Jamaluddin et al., 1977). Thus, high reduction of total sugar was observed in diseased seed than the healthy one. Ingale (1976) reported that Curvularia lunata, $C$. pallescens, Drechslera specifera and $D$. halodes var. tritici were found to increase the protein content while others, Fusarium moniliforme, F. semitectum, Aspergillus flavus, A. niger, Cephalosporium acremonium, Rhizoctonia spp. and Alternaria tenuis caused decrease.

These fungi, also found responsible for reduction of sugar content between 26.14 and $31.37 \%$ in seed. Seed borne infection of Drechslera oryzae decreases the starch and sugar content of grains between 25 to 85 and 71 to $89 \%$ respectively in rice, Jha (1993). Loss of lipid, nitrogen and starch due to storage fungi was also reported by Prasad et al., (1988) in coriander seed.

\section{Phenolic acid}

The phenolic acid traits revealed that the maximum phenolic acid contains were observed in healthy seed of sorghum, wheat, paddy and pearl millet, ranged between 3.62 
$\mu \mathrm{g} / \mathrm{g}$ to $6.92 \mu \mathrm{g} / \mathrm{g}$ and $2.65 \mu \mathrm{g} / \mathrm{g}$ to $4.79 \mu \mathrm{g} / \mathrm{g}$ recorded in infected seed. Among the healthy seed, maximum phenolic acid exhibited in pearl millet seed $6.92 \mu \mathrm{g} / \mathrm{g}$ and minimum were recorded in wheat seed $3.62 \mu \mathrm{g} / \mathrm{g}$. Maximum phenolic acid noticed in pearl millet seed $4.79 \mu \mathrm{g} / \mathrm{g}$ and minimum in paddy $2.65 \mu \mathrm{g} / \mathrm{g}$ among infected seeds. Since sugars are the precursors for the synthesis of phenolics, the depletion of sugars in seed due to seed borne fungi leads to reduced synthesis of phenolics compounds (Ushamalini et al., 1998). Gopalakrishnan et al., (2009) who reported that discolored grain infected by Sarocladium oryzae in rice, which contain phenols ranged from 0.21 to $0.37 \mathrm{mg} / \mathrm{g}$. Weider et al., (1999) also reported the phenolic acid in the range of 3.44 to 3.55 $\mathrm{mg} / \mathrm{kg}$ in healthy wheat seed. Similar findings have also been reported by Pandey et al., (2013) in corn seed, three phenolic acid were detected in the range of 0.57 to $4.6 \mu \mathrm{g} / \mathrm{g}$.

\section{Total phenol}

The highest total phenol content were recorded in healthy seed of sorghum, wheat paddy and pearl millet ranged between 2.96 $\mu \mathrm{g} / \mathrm{g}$ to $4.05 \mu \mathrm{g} / \mathrm{g}$ of seed. However, in respect of diseased seed the range of total phenol was $1.71 \mu \mathrm{g} / \mathrm{g}$ to $3.46 \mu \mathrm{g} / \mathrm{g}$ of seed. Maximum total phenol exhibited in wheat $(4.05 \mu \mathrm{g} / \mathrm{g})$ seed and minimum were in paddy seed $2.96 \mu \mathrm{g} / \mathrm{g}$ in disease free seeds. Maximum total phenol observed in sorghum seeds, i.e. $3.46 \mu \mathrm{g} / \mathrm{g}$ and minimum recorded in paddy seeds $1.71 \mu \mathrm{g} / \mathrm{g}$ among diseased seeds. It has been noticed that the healthy seed of sorghum, wheat, paddy and pearlmillet contain high total sugars, total phenols and high phenolic acid. However, the infected/ diseased seed contains very low quantity of total sugar, phenolic acid and total phenol. Nagavani and Kalappanavar (2006) identified resistant genotype of barley against Helminthosporium sativum and Cochliobolus sativum which contains high amount of total phenol $(3.46 \mathrm{mg} / \mathrm{g})$ over susceptible genotype $(2.09 \mathrm{mg} / \mathrm{g})$. In present investigations also, the total phenol contain in healthy seed was observed in the range of 2.96 to $4.05 \mu \mathrm{g} / \mathrm{g}$ and in diseased seed it was ranged between 1.71 to $3.46 \mu \mathrm{g} / \mathrm{g}$ of seed. Eisa et al., (2013) reported that the Bipolaris sorokiniana resistant genotype was strongly associated with high amount of total phenol (246 mg Gallic acid $\mathrm{g}^{-1}$ ) than the susceptible genotype (181.5 mg Gallic acid $\mathrm{g}^{-1}$ ) in wheat.

The healthy seed of sorghum, wheat, paddy and pearl millet contain high total sugar, total phenol and high phenoilic acid. However, the infected/ diseased seed contains very low quantity of total sugar, phenolic acid and total phenol.

\section{References}

Bhattacharya Kashinath and Raha Subrata, 2002 Deteriorative changes of Maize, Groundnut and Soybean seed by fungi in storage. Mycopathologia, 155: 135141.

Edwards*, W.M. and J. Curtis, 1943. Grain sorghum, their products and uses. ACE193, NM-229. Northern Regional Research Lab., U.S. Dept. Agric. Peoria.

Eisa, Musaed, Ramesh Chand and Arun K. Joshi, 2013. Biochemical and histochemical traits: A promising way to screen resistance against spot blotch (Bipolaris sorokiniana) of wheat. European J. Plant Pathology, 137(4): 805-820.

Gopalakrishanan Chellappan, Ayyanar Kamalakannan and Veeramuthu Valluvapridasan, 2009. Effect of seed borne Sarocladium oryzae, the incitant of rice sheat rot of rice seed quality. Journal of Plant Protection Research, 50(1): 98-102. 
Hahn*, D, L., W. Rooney and C.F. Earp, 1984. Tannins and Phenols of Sorghum. Cereal Food World. 29: 776-779.

Ingle*, P.T. 1976. Studies on seed borne mycroflora of hybrid. Jawar CSH-4 in Dhul and Jalgaon District. M.Sc. (Agri.) Thesis Mahatma Phule Agricultural University, Rahuri, India.

Jamaluddin Bilgrami, K.S. and T. Prasad, 1977. Change in protein in contents of Phaseolus mungo due to fungal flora. Curr. Sci., 46: 461.

Jha, D.K., 1993. A Textbook on seed pathology. Vikas Publishing House Pvt. Ltd., New Delhi, 18.
Nagaveni, T. and I.K. Kalappanavar, 2006. Biochemical factors imparting resistance to leaf blight of barley, Asian J. Bio. Sci., 1(2): 74-76.

Neucere*, N.J. and G. Sumrell, 1980. Chemical composition of different varieties of grain sorghum: J. Agric. Food Chem.28: 19.

Tripathi*, R.K., 1974. Head Fungi of sorghum, Phytopathotoxin and their effect seed germination. Indian Phytopath. 27(4): 499-501.

\section{How to cite this article:}

Gulhane A. R., Shilpa V. Khambalkar and Giri G. K. 2018. Biochemical Estimation of Healthy and Infected Graminicolous Seeds. Int.J.Curr.Microbiol.App.Sci. 7(07): 4113-4119. doi: https://doi.org/10.20546/ijcmas.2018.707.479 